\title{
Erratum to: Integrating concepts and models from development economics with land use change in the tropics
}

\author{
Charles A. S. Hall
}

Published online: 19 March 2010

(C) Springer Science+Business Media B.V. 2010

\section{Erratum to: Environ Dev Sustain (2006) 8:19-53 DOI 10.1007/s10668-005-0786-2}

Unfortunately, the word "Economics" has been misspelled in the article as "Econoimcs". The correct version of the article title is: "Integrating concepts and models from development economics with land use change in the tropics".

The online version of the original article can be found under doi:10.1007/s10668-005-0786-2.

C. A. S. Hall ( $\bowtie)$

Departments of Environmental and Forest Biology and Environmental Science, College of Environmental Science and Forestry State University of New York, Syracuse, NY 14850, USA

e-mail: chall@esf.edu 